\title{
Screening of Antioxidant and Antimicrobial Properties of the Syzygium jambos L.
}

\author{
Mst. Marium Begum², Majidul Haque ${ }^{1}$, Md. Reyad-ul-Ferdous ${ }^{5}$, Moynul Hasan ${ }^{3}$, Hasan $^{2}$ Tarek $^{3}$, \\ Md. Noor-A-Alam ${ }^{3}$, Md. Belal Hossain ${ }^{3}$, Md. Nazir Uddin ${ }^{3}$, Taslima Begum ${ }^{4}$, \\ Choudhury Mahmood Hasan, ${ }^{1, *}$
}

${ }^{1}$ Department of Pharmaceutical Chemistry, Faculty of Pharmacy, University of Dhaka, Dhaka-1000, Bangladesh

${ }^{2}$ Department of Pharmaceutical Technology, Faculty of Pharmacy, University of Dhaka, Dhaka-1000, Bangladesh

${ }^{3}$ Department of Pharmacy, Dhaka International University, Dhaka-1213, Bangladesh

${ }^{4}$ Department of Pharmacy, Primeasia University, Dhaka-1213, Bangladesh

${ }^{5}$ Department of Pharmaceutical Sciences, North South University, Dhaka-1229, Bangladesh

\section{Email address:}

cmhasan@gmail.com (C. M. Hasan), rockyreyad@yahoo.com (M. R. Ferdous)

\section{To cite this article:}

Mst. Marium Begum, Majidul Haque, Md. Reyad-ul-Ferdous, Moynul Hasan, Hasan Tarek, Md. Noor-A-Alam, Md. Belal Hossain, Md. Nazir Uddin, Taslima Begum, Choudhury Mahmood Hasan. Screening of Antioxidant and Antimicrobial Properties of the Syzygium jambos L. American Journal of BioScience. Special Issue: Pharmacological and Phytochemicals Investigation. Vol. 3, No. 2-1, 2015, pp. 23-26. doi: 10.11648/j.ajbio.s.2015030201.15

\begin{abstract}
Syzygium jambos (L.) Alstone belonging to the Myrtaceae family have been investigated for evaluation of their biological activities namely antioxidant and antimicrobial activity. The $n$-hexane, carbon tetrachloride, chloroform, aqueous soluble fractions of methanolic extract as well as crude methanolic extract of stem barks of Syzygium jambos were evaluated for their free radical scavenging activity. The methanolic extract and aqueous soluble fractions of stem barks of Syzygium jambos exhibited significant antioxidant activity with the $\mathrm{IC}_{50}$ value of $36.36 \mu \mathrm{g} / \mathrm{ml}$ and $44.744 \mu \mathrm{g} / \mathrm{ml}$ respectively whereas chloroform, carbon tetrachloride and hexane soluble fraction of stem barks exhibited mild antioxidant activity with the $\mathrm{IC}_{50}$ value $191.018,257.102,414.79 \mu \mathrm{g} / \mathrm{ml}$ respectively. The crude extract, along with $n$-hexane, carbon tetrachloride and chloroform partitionates of the crude extract of Syzygium jambos were screened for their antimicrobial activity against a wide range of both gram-positive and gram-negative bacteria by the disc diffusion method. The results obtained were compared with that of a standard antibiotic, ciprofloxacin. All the fractions of Syzygium jambos exhibited mild activity against most of the test organism.
\end{abstract}

Keywords: Syzygium jambos, Medicinal Plant, Identification, Anti-oxidant, Antimicrobial Activity

\section{Introduction}

In the plant kingdom there is a remedy for every disease ${ }^{[1]}$. Two hundred and fifty years ago, there were few or no synthetic medicines. The plants were the main source of drugs for the world's population. Today, $75 \%$ of the world's population, the poor $3 / 4^{\text {ths }}$, still relies on those plants and other tools of traditional medicine ${ }^{[2]}$. Plants have provided a source of inspiration for novel drug compounds, as plant derived medicines have made large contributions to human health and well-being ${ }^{[3]}$.

The number of higher plant species (angiosperms and gymnosperms) on this planet is estimated at $250,000^{[4]}$, with a lower level at $215,000^{[5]}$ and an upper level as high as
$500,000^{[6,7]}$. Of these, only about $6 \%$ have been screened for biologic activity, and a reported $15 \%$ have been evaluated phytochemically ${ }^{[8]}$. Chemical diversity of secondary plant metabolites that results from plant evolution may be equal or superior to that found in synthetic combinatorial chemical libraries. Success in natural products research is conditioned by a careful plant selection, based on various criteria such as chemotaxonomic data, ethnomedical information, field observations or even random collection. One main strategy in the isolation of new leads consists of the so-called bioactivity-guided isolation, in which pharmacological or biological assays are used to target the isolation of bioactive compounds ${ }^{[9]}$.

The work described in this dissertation is an attempt to 
isolate and characterize the chemical constituents of medicinal plants, viz., Syzygium jambos (Fam. Myrtaceae) and to evaluate the possible cytotoxic profiles of the crude extracts

\section{Materials and Method}

\subsection{Plant Material and Extract Preparation}

Collection and preparation of the plant (Syzygium jambos) material: Plant sample of Syzygium jambos were collected from Gazipur, Bangladesh and was identified by an expert taxonomist of Botany Department, University of Dhaka (plant reference no. is DUSH7179). The stem barks were separated, cut into small pieces, sun dried for several days followed by oven dried for 24 hours at $40^{\circ} \mathrm{C}$ to facilitate grinding and finally crushed into course powder.

Extraction and fractionation: About 200gram of powdered stem barks in methanol for two weeks with occasional shaking. The mixture was filtered, concentrated at $39^{\circ} \mathrm{C}$ to have a concentrated crude extract. 5 gram of the extract was subjected to solvent-solvent partition for investigation of the biological activities and the remaining amount was used for chemical investigation. The concentrated methanol extract (5 g) was fractionated by modified Kupchan method ${ }^{[10,11]}$ and the resultant partitionates i.e., petroleum ether, carbon tetrachloride, chloroform and aqueous soluble materials were used for different biological screenings.

\subsection{Antioxidant Activity of the Purified Crude Extract of S. jambos}

The free radical scavenging activity of the plant extractives was determined on the stable radical produced by 1,1diphenyl-2-picrylhydrazyl (DPPH) ${ }^{[12]} 2.0 \mathrm{ml}$ of a methanol solution of the sample (extractives/ control) at different concentration $(500 \mu \mathrm{g} / \mathrm{ml}$ to $0.977 \mu \mathrm{g} / \mathrm{ml})$ were mixed with 3.0 $\mathrm{ml}$ of a DPPH methanol solution $(20 \mu \mathrm{g} / \mathrm{ml})$. After $30 \mathrm{~min}$ reaction period at room temperature in dark place the absorbance was measured at $517 \mathrm{~nm}$ against methanol as blank by UV spetrophotometer.

Inhibition of free radical DPPH in percent (I\%) was calculated as follows:

$$
(\mathrm{I} \%)=\left(1-\mathrm{A}_{\text {sample }} / \mathrm{A}_{\text {blank }}\right) \times 100
$$

Where $A_{\text {blank }}$ is the absorbance of the control reaction (containing all reagents except the test material).

Extract concentration providing $50 \%$ inhibition $\left(I C_{50}\right)$ was calculated from the graph plotted inhibition percentage against extract concentration.

\subsection{Antimicrobial Activity of the Purified Crude Extract of S. jambos}

The antimicrobial activity of the extractives was determined by the disc diffusion method ${ }^{[11]}$ against 5 gram positive bacteria, 8 gram negative bacteria and 4 fungi. The organisms were collected as pure cultures from the Institute of Nutrition and Food Sciences (INFS). The in vitro antimicrobial study was designed to investigate the antibacterial as well as antifungal spectrum of the crude extracts by observing the growth response. Minimum inhibitory concentration (MIC) required to kill the susceptible microbial strain is used to determine and to evaluate the extracts as potential source of antibiotics. But in the present experiment MIC was not studied as antimicrobial activity of the two plant extracts was found as moderate to mild.

\section{Results and Discussion}

In this investigation, MESSJ showed the highest free radical scavenging activity with an $\mathrm{IC}_{50}$ value of $36.36 \mu \mathrm{g} / \mathrm{ml}$ for the stem barks of $S$. jambos (Fig-1). At the same time the AQSF also exhibited strong antioxidant potential having $\mathrm{IC}_{50}$ value $44.744 \mu \mathrm{g} / \mathrm{ml}$ and CTCSF and CLFSF also revealed moderate scavenging activity having $\mathrm{IC}_{50}$ values 257.102 $\mu \mathrm{g} / \mathrm{ml}$ and $191.018 \mu \mathrm{g} / \mathrm{ml}$ respectively. HSF revealed week scavenging activity having $\mathrm{IC}_{50}$ value $414.79 \mu \mathrm{g} / \mathrm{ml}$.

The Methanolic extract of whole plant of $S$. jambos (MESSJ) and different partitionates i.e. hexane (HSF), carbon tetrachloride (CTCSF), and chloroform (CLFSF) soluble partitionate of the methanolic extract of whole plant of $S$. jambos were subjected to antimicrobial screening with a concentration of $400 \mu \mathrm{g} / \mathrm{disc}$ in every case. The results are given in the Table-1.

All the fractions showed no zone of inhibition. The plant $S$. jambos have significant anti microbial action against all bacteria and fungi.

Table 1. Antimicrobial activity of test samples of S. jambos.

\begin{tabular}{|c|c|c|c|c|c|c|}
\hline \multirow{2}{*}{ Test microorganisms } & \multicolumn{6}{|c|}{ Diameter of zone of inhibition (mm) } \\
\hline & MESF & HSF & CTCSF & CLFSF & AQSF & Ciprofloxacin \\
\hline \multicolumn{7}{|l|}{ Gram positive bacteria } \\
\hline Bacillus cereus & - & - & 9 & 8 & - & 55 \\
\hline Bacillus megaterium & - & - & 8 & 7 & - & 54 \\
\hline Bacillus subtilis & - & - & - & - & - & - \\
\hline Staphylococcus aureus & - & - & 10 & 10 & - & 51 \\
\hline Sarcina lutea & - & - & - & - & - & - \\
\hline \multicolumn{7}{|l|}{ Gram negative bacteria } \\
\hline Escherichia coli & - & - & 17 & 7 & - & 50 \\
\hline Pseudomonas aeruginosa & - & - & - & - & - & - \\
\hline Salmonella paratyphi & - & - & - & - & - & - \\
\hline Salmonella typhi & - & - & - & - & - & - \\
\hline
\end{tabular}




\begin{tabular}{|c|c|c|c|c|c|c|}
\hline \multirow{2}{*}{ Test microorganisms } & \multicolumn{6}{|c|}{ Diameter of zone of inhibition (mm) } \\
\hline & MESF & HSF & CTCSF & CLFSF & AQSF & Ciprofloxacin \\
\hline Shigella boydii & - & - & 12 & - & - & 50 \\
\hline Shigella dysenteriae & - & - & - & - & - & - \\
\hline Vibrio mimicus & - & - & - & - & - & - \\
\hline Vibrio parahemolyticus & - & - & - & - & - & - \\
\hline \multicolumn{7}{|l|}{ Fungi } \\
\hline Candida albicans & - & - & 22 & - & - & 50 \\
\hline Aspergillus niger & - & - & - & - & - & - \\
\hline Sacharomyces cerevacae & - & - & 12 & 7 & - & 50 \\
\hline
\end{tabular}

\section{$I_{50}$ of Different Extractives of Stem Barks of S. jambos}

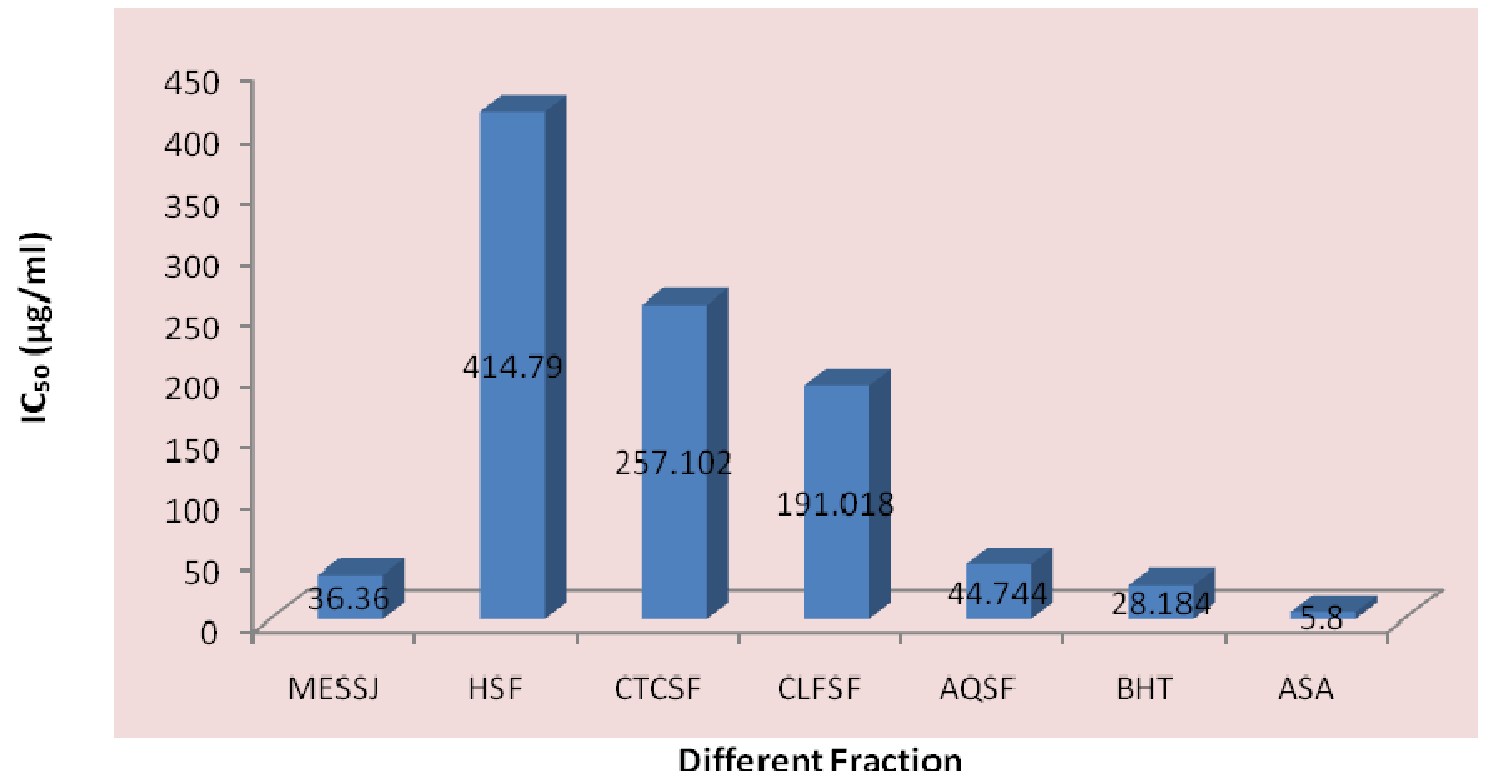

Fig- 1. IC ${ }_{50}$ values of the standard and partitionates of S. jambos.

\section{Conclusion}

The chloroform soluble fraction and the carbon tetrachloride soluble fraction of the stem bark of $S$. jambos exhibited mild to moderate antimicrobial activity. Methanolic extract of stem barks and the chloroform soluble fraction of this plant showed significant free radical scavenging activity. In addition, the crude methanolic extract of stem barks, the chloroform partitionate, and carbon tetrachloride of the crude extract of the plant gave better cytotoxic effect. In conclusion, considering the potential bioactivity, this plant can be studied extensively to find out their unexplored efficacy and to rationalize their use as traditional medicine.

\section{Abbreviations}

$\mathrm{ME}=$ Methanolic extract; $\mathrm{PESF}=$ Pet-ether soluble fraction; $\mathrm{CTCSF}=$ Carbon tetrachloride soluble fraction; CSF =Chloroform soluble fraction; AQSF =Aqueous soluble fraction of the methanolic extract of $S$. jambos.

\section{References}

[1] Farnsworth N.R., Akerele O., Bingel A.S., Soejarto D.D., Guo Z., 1985.Medicinal plants in therapy. Bull W H O 63: 965-981

[2] Kumar S., Kumar R., Khan A., 2011, Medicinal plant resources: manifestation and prospects of life- sustaining healthcare system, Cont. J. Biol. Sci., 4 (1): $19-29$

[3] Hong-Fang J., Jue-Juan L., Hong-Yu Z., 2009, Natural products and drug discovery. Can thousands of years of ancient medical knowledge lead us to new and powerful drug combinations in the fight against cancer and dementia, EMBO Rep. Mar 2009; 10(3): 194-200

[4] Ayensu E.S., DeFilipps R. A., 1978, Endangered and Threatened Plants of the United States. Washington,DC:Smithsonian Institution. Retrieve 11/08/2014. http://www.cnps.org/cnps/rareplants/inventory/references.php

[5] Cronquist, A. 1988. The Evolution and Classification of Flowering Plants. 2nd ed. Bronx, NY: New York Botanical Garden. 555 p. 
[6] Tippo O., Stern W. L., 1977, Humanistic Botany. New York:W.W. Norton

[7] Schultes R.E., 1972, The future of plants as sources of new biodynamic compounds: Plants in the Development of Modern Medicine (Swain T, ed). Cambridge, MA: Harvard University Press, 103-124

[8] Verpoorte R., 2000. Pharmacognosy in the new millennium: lead finding and biotechnology. J Pharm Pharmacol. 52, 253262

[9] Burbaum J.J., Ohlmeyer M.H., Reader J.C., Henderson I, Dillard L.W., Li J., Randle T.L.,Sigal N.H., Chelsky D., Baldwin J.J., 1995, Proc Natl Acad Sci U S A, 92(13): 60276031
[10] Van Wagenen B.C., Larsen R., Cardellina J.H. II, Ran dazzo D., Lidert Z.C., Swithenbank C., 1993. Ulosantoin, a potent insecticide from the sponge Ulosa ruetzleri. J. Org. Chem. 58, $335-337$

[11] Md. Reyad-Ul-Ferdous, Sayma Akhter, Md. Zahirul Islam Khan, Md. Eshak Khan, Md. Atiqul Islam, Md. Sharif Ullah. Ex-Vivo anti-inflammatory and antimicrobial activities of the leaves of Bauhinia acuminate. American Journal of Life Sciences. 2014; 2(5): 267-270. doi: 10.11648/j.ajls.20140205.13.

[12] Md. Reyad-ul-Ferdous, Mosharaf Hossen and Fazle Noor Biswas. In-vitro potential antimicrobial and antioxidant activities of Lablab niger leaves. International Journal of Pharma Sciences and Research 2014; 5(6): 257-261. 